\title{
Viral Hepatitis Strategic Information to Achieve Elimination by 2030: Key Elements for HIV Program Managers
}

Yvan Hutin ${ }^{1}$, MD, PhD; Daniel Low-Beer ${ }^{1}$, PhD; Isabel Bergeri ${ }^{1}$, PharmD MPH; Sarah Hess ${ }^{1}$, MPH; Jesus Maria Garcia-Calleja ${ }^{1}$, MPH, MD; Chika Hayashi ${ }^{1}$, MHS; Antons Mozalevskis ${ }^{2}$, MD; Annemarie Rinder Stengaard ${ }^{2}$, MSc; Keith Sabin $^{3}$, MPH, PhD; Hande Harmanci ${ }^{1}$, MD, DrPH; Marc Bulterys ${ }^{1}$, MPH, MD, PhD

\footnotetext{
${ }^{1} \mathrm{HIV}$ and Hepatitis Department, World Health Organization, Geneva, Switzerland

${ }^{2}$ Regional Office for Europe, World Health Organization, Copenhagen, Denmark

${ }^{3}$ Joint United Nations Programme on HIV/AIDS, Geneva, Switzerland
}

\section{Corresponding Author:}

Yvan Hutin, MD, PhD

HIV and Hepatitis Department

World Health Organization

Avenue Appia, 20

Geneva, 1211

Switzerland

Phone: 41227914166

Fax: 41227911580

Email: hutiny@who.int

\section{Abstract}

Evidence documenting the global burden of disease from viral hepatitis was essential for the World Health Assembly to endorse the first Global Health Sector Strategy (GHSS) on viral hepatitis in May 2016. The GHSS on viral hepatitis proposes to eliminate viral hepatitis as a public health threat by 2030. The GHSS on viral hepatitis is in line with targets for HIV infection and tuberculosis as part of the Sustainable Development Goals. As coordination between hepatitis and HIV programs aims to optimize the use of resources, guidance is also needed to align the strategic information components of the 2 programs. The World Health Organization monitoring and evaluation framework for viral hepatitis $\mathrm{B}$ and $\mathrm{C}$ follows an approach similar to the one of HIV, including components on the following: (1) context (prevalence of infection), (2) input, (3) output and outcome, including the cascade of prevention and treatment, and (4) impact (incidence and mortality). Data systems that are needed to inform this framework include (1) surveillance for acute hepatitis, chronic infections, and sequelae and (2) program data documenting prevention and treatment, which for the latter includes a database of patients. Overall, the commonalities between HIV and hepatitis at the strategic, policy, technical, and implementation levels justify coordination, strategic linkage, or integration, depending on the type of HIV and viral hepatitis epidemics. Strategic information is a critical area of this alignment under the principle of what gets measured gets done. It is facilitated because the monitoring and evaluation frameworks for HIV and viral hepatitis were constructed using a similar approach. However, for areas where elimination of viral hepatitis requires data that cannot be collected through the HIV program, collaborations are needed with immunization, communicable disease control, tuberculosis, and hepatology centers to ensure collection of information for the remaining indicators.

(JMIR Public Health Surveill 2017;3(4):e91) doi: 10.2196/publichealth.7370

\section{KEYWORDS}

hepatitis; HIV; surveillance; evaluation

\section{Introduction}

The Global Hepatitis Report [1] indicated that in 2015, 1.34 million persons died from the consequences of viral hepatitis. Hence, mortality from viral hepatitis is at par with tuberculosis, and higher than the HIV infection or malaria [2]. More than
$90 \%$ of this burden is due to cirrhosis and hepatocellular carcinoma, the sequelae of infections with hepatitis $\mathrm{B}$ virus (HBV) and hepatitis C virus (HCV) [1]. In May 2016, the World Health Assembly endorsed the Global Health Sector Strategy (GHSS) for 2016-2021 on viral hepatitis that proposes to eliminate viral hepatitis as a public health threat by 2030 (elimination is defined as a $90 \%$ reduction in new chronic 
infections and a $65 \%$ reduction in mortality compared with the 2015 baseline.) [3]. The World Health Organization (WHO) conceived this strategy using the same universal health coverage and public health frameworks that were used for strategies for HIV [4] and sexually transmitted infections (STIs) [5]. These 3 strategies were developed and adopted together; their 5 strategic directions are as follows: (1) information for focused action, (2) interventions for impact, (3) delivering for equity, (4) financing for sustainability, and (5) innovation for acceleration.

To eliminate viral hepatitis as a public health threat, the GHSS proposes to scale up prevention interventions currently available, such as universal immunization of children against hepatitis B, including a timely birth dose to prevent mother-to-child transmission [6]. In addition, it also introduces newer programmatic components, such as testing and treatment (older policy responses did not address chronic infection). Testing and treatment services for $\mathrm{HBV}, \mathrm{HCV}$, and $\mathrm{HIV}$ infections can use similar programmatic and delivery approaches. Thus, implementation of hepatitis and HIV interventions at the global, regional, and country level is being progressively considered as a coordinated approach where it is possible and improves impact and efficiency.

Strategic information can be defined as data collected at all administrative levels to inform policy and program decisions. The WHO published consolidated strategic information guidelines for HIV, including a monitoring and evaluation framework that includes 10 core indicators [7]. In 2016, the WHO also published guidance for strategic information in the field of viral hepatitis, including surveillance [8], and monitoring and evaluation [9]. This paper summarizes the approach proposed by the WHO to collect, analyze, and use viral hepatitis strategic information so that HIV and hepatitis services have aligned approaches in terms of service delivery and data management.

\section{HIV, HBV, and HCV: Similarities and Differences}

\section{Similarities}

In infected persons, HIV, HBV, and HCV are present in blood and most body fluids. Hence, these viruses share a number of modes of transmission, including mother-to-child, blood-borne, and sexual. HIV, HBV, and HCV lead to infections that may be silent for a number of years before consequences of infections lead to fatal sequelae. HIV, HBV, and HCV infections can be prevented with safer sex, interventions to reduce mother-to-child transmission, blood safety, standard universal precautions in health care and other settings, and harm reduction interventions for people who inject drugs (PWID). Specific risk groups (eg, PWID and men who have sex with men) are often disproportionally affected by HIV, HBV, and HCV and can be reached through coordinated health sector and community-based services, using the people-centered approaches recommended by the Sustainable Development Goals (SDGs). Mortality from chronic HBV and HCV infections can be reduced by testing and treatment, similar to HIV.

\section{Differences}

Aside from the many similarities between HIV, HBV, and HCV, there are a number of differences that need to be understood for optimized program implementation, including surveillance, monitoring, and evaluation.

\section{Burden}

Globally, HBV and HCV infections are more prevalent than HIV infection (Table 1) and may be distributed differently by region. However, in the absence of treatment, the case fatality of HIV is higher, and deaths tend to occur earlier in the course of the infection (50\% within 10 years of infection), and therefore at an earlier age [2]. Regional variations in the differences in prevalence and mortality between HIV, HBV, and HCV have implications in the way that these areas of work may relate, from coordination to strategic linkages or integration, according to the magnitude of the epidemics [10].

\section{New Infections}

New infections with HIV are asymptomatic in most cases or may result in a nonspecific illness. Among adults, new infections with HBV and HCV lead to acute hepatitis in less than $50 \%$ of instances. The burden of disease from acute hepatitis is small in comparison with the burden from chronic infections [1]. However, if identified and reported in the context of enhanced case reporting, these cases of acute hepatitis can provide critical information on incidence trends and risk factors [8]. For HBV, this is facilitated by the availability of a marker of recent infection (IgM antibodies against HBV core antigen [anti-HBc $\operatorname{IgM}]$ ). For $\mathrm{HCV}$, in the absence of a biomarker of recent infection, case definitions are available for the surveillance of acute hepatitis $C$. The case definition of acute hepatitis $C$ is an acute hepatitis that is non-A, non-B, and non-E and positive for HCV biomarkers [8].

\section{Chronic Infections}

In the case of HIV infection, most untreated persons will develop acquired immunodeficiency syndrome (AIDS) (with the exception of about 5\% who are "elite controllers") [11]. In the case of hepatitis, some patients newly infected with HBV and HCV spontaneously clear infection $(80 \%-95 \%$ for HBV and about $20 \%$ for HCV) [8]. Hence, for hepatitis, it is relevant to use biomarkers to differentiate evidence of past or present infection from evidence of present (current) infection. Markers of past or present infection include antibody to HBV core antigen (total anti-HBc) and antibody to HCV (anti-HCV). Markers of present infection include hepatitis B surface antigen (HBsAg) and HCV RNA. As for HIV, the age at which HBV and HCV infection occurs influences the natural history. For $\mathrm{HBV}$, infections acquired in the first 5 years of life most often lead to chronic infections and sequelae [12]. They account for the largest proportion of the burden of disease affecting adults. In contrast, the incidence of $\mathrm{HCV}$ infection in children is generally low, and infections acquired in childhood are probably of a better prognosis [13]. 
Table 1. Key characteristics of hepatitis B virus (HBV), hepatitis C virus (HCV), and HIV infection, including epidemiology, clinical manifestations, biomarkers, routes of transmission, prevention, and treatment.

\begin{tabular}{|c|c|c|c|}
\hline Characteristics & Hepatitis B virus (HBV) & Hepatitis $\mathrm{C}$ virus (HCV) & HIV \\
\hline \multicolumn{4}{|l|}{ Estimates of epidemiology and burden } \\
\hline Prevalence (millions of infections) & 257 & 71 & 33 \\
\hline Annual mortality (millions of deaths) & 0.887 & 0.399 & 1.341 \\
\hline \multicolumn{4}{|l|}{ Clinical manifestations } \\
\hline Clinical manifestations of new infections & $\begin{array}{l}\text { Acute hepatitis (uncommon in } \\
<5 \text { years, } 50 \% \text { of new infections } \\
\text { among persons aged } \geq 5 \text { years) }\end{array}$ & $\begin{array}{l}\text { Acute hepatitis }(<20 \% \text { of new } \\
\text { infections) }\end{array}$ & $\begin{array}{l}\text { Nonspecific clinical manifes- } \\
\text { tations of acute HIV infec- } \\
\text { tion }\end{array}$ \\
\hline Spontaneous clearance of infection & $80 \%-95 \%$ of new infections & $20 \%$ of new infections & None \\
\hline Long-term complications & $\begin{array}{l}\text { Cirrhosis and hepatocellular car- } \\
\text { cinoma }\end{array}$ & $\begin{array}{l}\text { Cirrhosis and hepatocellular car- } \\
\text { cinoma }\end{array}$ & $\begin{array}{l}\text { Chronic infection leading to } \\
\text { immune suppression }\end{array}$ \\
\hline
\end{tabular}

\section{Biomarkers}

New/recent infection

Past or present infection

Present infection

\section{Routes of transmission}

Perinatal

Sexual

Blood-borne

Vaccine

\section{Approach to prevention}

Mother-to-child transmission

Prevention of other new infections

Treatment

$$
\text { IgM anti-HBc }{ }^{\mathrm{b}} \quad \mathrm{None}^{\mathrm{c}}
$$

\section{Total anti-HBc}

$\mathrm{HBsAg}^{\mathrm{d}}$

Delivery and uncommonly, before birth

$$
++^{\mathrm{g}}
$$

++++

Yes

Universal immunization of infants, starting at birth $+/-\mathrm{HBIg}^{\mathrm{h}}$ $+/-$ antivirals during pregnancy

Universal immunization, safe injection practices, infection control, blood safety, and safe sex

$+++$

No $\operatorname{sex}$
Anti-HCV
HCV RNA ${ }^{\mathrm{e}}$ or $\mathrm{HCV}$ core antigen

Uncommon $^{\mathrm{f}}$

+/- ${ }^{\mathrm{g}}$ Common in HIV-infected men who have sex with men

Cure mothers before pregnancy

Safe injection practices, infection control, blood safety, and safe

Treatment available leading to cure after short course
Test and treat

Some options available with nucleic acid testing or "recency" serological tests

Anti-HIV

Anti-HIV

Before, during, and after birth

$+++$

$++$

No

Safe sex, voluntary surgical male circumcision, safe injection practices, infection control, blood safety, preexposure prophylaxis

Lifelong treatment with a combination of medicines

${ }^{a}$ AIDS: acquired immunodeficiency syndrome.

${ }^{\mathrm{b}}$ Anti-HBc: antibody to the hepatitis B core antigen.

${ }^{\mathrm{c}} \mathrm{RNA}$ or core antigen positive in the absence of anti-HCV suggests recent $\mathrm{HCV}$ infection.

${ }^{\mathrm{d}} \mathrm{HBs}$ Ag: hepatitis B surface antigen.

${ }^{\mathrm{e}} \mathrm{RNA}$ : ribonucleic acid.

${ }^{\mathrm{f}}$ Risk of mother-to-child transmission is higher among HIV-infected pregnant women.

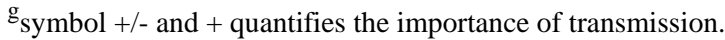

h HBIg: Hepatitis B immune globulin.

\section{Sequelae}

Ten years after initial infection, without treatment, about 50\% of persons with HIV infection will have developed AIDS [14]. AIDS may be recognized by infectious disease physicians or the diagnosis may be missed if the patient dies of other opportunistic infections. In contrast, HBV and HCV infections lead to cirrhosis and hepatocellular carcinoma, two conditions that may be primarily managed by internists or gastroenterologists rather than infectious disease physicians in settings where patients have access to specialized care. The 
duration between infection and death is longer in the case of $\mathrm{HIV}$, in the range of 20 to 30 years [15-17]. Other cofactors (eg, alcohol use, metabolic syndrome, toxins, and substance abuse) can also affect the risk of developing cirrhosis or hepatocellular carcinoma. As a result, the hepatitis virus infection that led to these sequelae may not be recognized or reported as the cause of death. This complicates the measurement of the burden of disease associated with HBV and HCV infection [18]. Historically, the Global Burden of Disease took a number of years to attribute cirrhosis and hepatocellular carcinoma to HBV and HCV infections [18], and the current approach still does not take into account the extrahepatitic manifestation of the HCV infection [19].

\section{Transmission and Prevention}

$\mathrm{HIV}, \mathrm{HBV}$, and $\mathrm{HCV}$ can be transmitted through the same routes (Table 1). However, the relative importance of these routes varies according to the viruses. $\mathrm{HBV}$ is often transmitted through percutaneous, sexual, and perinatal routes. HIV is most often transmitted through sexual contacts. Injection drug use is also a common route of HIV transmission, but health care injections are an uncommon source of infection, even though outbreaks have occurred [20,21]. HCV is more often transmitted through the percutaneous route and accounts for the largest number of health care injections-associated infections [20]. Despite these differences in the relative importance of the various routes of transmission, methods of primary prevention do not differ (Table 1). However, for HBV, a safe and effective vaccine is also available [6]. Three doses of hepatitis B vaccine, with the first one administered soon after birth, can prevent the majority of chronic HBV infections [6]. Recommendations for the prevention of mother-to-child transmission also vary for the 3 viruses: immunoprophylaxis to prevent mother-to-child transmission of $\mathrm{HBV}$ and antiretroviral treatment for mother and child against HIV. Mother-to-child transmission of HCV is rare, and there is no specific approach to prevent it [22].

\section{Treatment}

As of 2016, treatment for HBV infection was in most cases lifelong. A single antinucleos(t)ide with a high barrier to resistance is sufficient to achieve viral suppression for patients who are eligible for treatment [23]. Hence, from a data management point of view, the approach to monitoring treatment is similar to HIV. Since 2013, HCV can be cured through a short-course treatment of a few months [13]. This revolution in curative treatment led to a new momentum for elimination. Hence, the approach to monitoring $\mathrm{HCV}$ treatment is more similar to curable infections such as tuberculosis. All $\mathrm{HCV}$-infected patients are potentially eligible for treatment. Coinfections with any combination of the 3 viruses require specific management considerations (see Table 1).

\section{GHSS on Viral Hepatitis}

The 2014 World Health Assembly requested the WHO to examine the feasibility of eliminating hepatitis B and C. In 2015, the SDGs committed to combating viral hepatitis (Target 3.3) [24]. As a result, the WHO coordinated a think tank to examine options. As part of this work, a mathematical model suggested that if the viral hepatitis response reached 5 synergistic prevention and treatment service coverage targets (Table 2), hepatitis B and C could be eliminated as a public health threat $[25,26]$. These 5 interventions now endorsed by a World Health Assembly resolution are as follows: (1) hepatitis B immunization, (2) prevention of mother-to-child transmission of HBV, (3) blood and injection safety, (4) prevention of transmission among persons who inject drugs through comprehensive harm reduction services, and (5) testing and treatment. Service coverage targets for 2030 with respect to testing and treatment are $90 \%$ of patients diagnosed and $80 \%$ of patients eligible treated (using a logic similar to $90 \%$ of people with HIV diagnosed, $90 \%$ of people diagnosed with HIV treated, and $90 \%$ of those on treatment virally suppressed by 2020 for HIV targets) [4].

\section{Monitoring Framework for Viral Hepatitis B and C}

\section{Levels and Indicators}

The WHO proposed a monitoring and evaluation framework for viral hepatitis B and C (Multimedia Appendix 1) that, similar to the 10 core indicators recommended for HIV, follows the result chain, from (1) context and needs to (2) input, (3) output and outcomes, and (4) impact [9].

\section{Context}

Given the focus on chronic HBV and HCV infections, prevalence of infection in the population is the best reflection of context and needs (C.1), similar to what is being used for HIV.

\section{Input}

Input refers to systems and resources available for hepatitis elimination. One of the most challenging service coverage targets of the GHSS is to increase the proportion diagnosed among those who are infected (30\% by 2020 and $90 \%$ by 2030 ; Table 2). This will require a substantial increase in the capacity to test individuals for HBV or HCV infection. Hence, the WHO selected the number of health care facilities that are able to test for $\mathrm{HBV}$ and $\mathrm{HCV}$ infections per 100,000 people as a core input indicator (C.2).

\section{Output and Outcomes}

\section{Prevention}

Three core prevention indicators reflect modes of transmission that are key for hepatitis. These include coverage of the third dose of hepatitis B vaccine and of timely birth dose (hepatitis $B$ vaccine birth dose or other methods to prevent mother-to-child transmission of HBV infection) (C.3), the number of syringe and needle sets distributed to persons who inject drugs (C.4) [27], and the proportion of safe injections at the health care facility level (C.5) [28]. Indicators reflecting sexual transmission are not included among these core indicators because sexual transmission accounts for a lower proportion of $\mathrm{HBV}$ and $\mathrm{HCV}$ infections than HIV [29]. 
Table 2. Global service coverage targets that would eliminate $\mathrm{HBV}^{\mathrm{a}}$ and $\mathrm{HCV}^{\mathrm{b}}$ as public health threats, 2015-2030.

\begin{tabular}{|c|c|c|c|}
\hline Target areas & Baseline 2015 & 2020 target & 2030 target \\
\hline \multicolumn{4}{|l|}{ Service coverage } \\
\hline \multicolumn{4}{|l|}{ Prevention } \\
\hline Three-dose HBV for infants (coverage $\%$ ) & 84 & 90 & 90 \\
\hline $\begin{array}{l}\text { Prevention of mother-to-child transmission of HBV: hepatitis } \\
\text { B birth-dose vaccination or other approaches (coverage \%) }\end{array}$ & 39 & 50 & 90 \\
\hline \multicolumn{4}{|l|}{ Blood and injection safety } \\
\hline $\begin{array}{l}\text { Blood safety: donations screened with quality assurance } \\
\text { (coverage \%) }\end{array}$ & 97 & 95 & 100 \\
\hline Injection safety: use of engineered devices ${ }^{\mathrm{c}}($ coverage $\%)$ & 5 & 50 & 90 \\
\hline $\begin{array}{l}\text { Harm reduction (sterile syringe/needle set distributed per } \\
\text { person per year for people who inject drugs [PWID]) }\end{array}$ & 20 & 200 & 300 \\
\hline \multicolumn{4}{|l|}{ Treatment } \\
\hline Diagnosis of $\mathrm{HBV}$ and $\mathrm{HCV}$ (coverage \%) & $9-20$ & 30 & 90 \\
\hline Treatment of HBV and HCV & $7 \%-8 \%$ & $\begin{array}{l}5 \text { million (HBV) and } 3 \\
\text { million (HCV) }\end{array}$ & $80 \%$ eligible treated \\
\hline \multicolumn{4}{|l|}{ Impact leading to elimination } \\
\hline Incidence of chronic $\mathrm{HBV}$ and $\mathrm{HCV}$ infections & 6-10 million & $30 \%$ reduction & $90 \%$ reduction \\
\hline Mortality from chronic HBV and HCV infections & 1.34 million & $10 \%$ reduction & $65 \%$ reduction \\
\hline
\end{tabular}

${ }^{\mathrm{a}} \mathrm{HBV}$ : hepatitis B virus.

${ }^{\mathrm{b}} \mathrm{HCV}$ : hepatitis $\mathrm{C}$ virus.

${ }^{\mathrm{c}}$ Although the service coverage target is about output (adoption of reuse prevention injection devices), the C.5 indicator focuses on outcome (provision of safe injections).

\section{Cascade of Care}

Using an approach very similar to HIV, the indicators of the cascade of care (for HBV) or cure (for HCV) include the proportion of people living with viral hepatitis diagnosed (C.6), treatment coverage (in the case of HBV infection, C.7.a) or initiation (in the case of $\mathrm{HCV}$ infection, C.7.b), and treatment outcome, which includes the proportion of people on treatment who are virally suppressed (C.8.a, for HBV infection) or the proportion of people cured among those who completed treatment (C.8.b, for HCV infection). In the case of HBV infection, a high proportion of people with chronic infection are not eligible for treatment [23]. Hence, the coverage of linkage to care among those diagnosed is also important as some diagnosed patients will require long-term follow-up to determine when they become eligible for treatment (Indicator A.8) [9].

\section{Impact}

Similar to HIV, the results chain is linked to impact (incidence and mortality). These are the parameters upon which elimination is defined (ie, $90 \%$ reduction in incidence and $65 \%$ reduction in mortality compared with the 2015 baseline). The WHO designated the cumulative incidence of HBV infection among children at 5 years of age (C.9.a) to evaluate progress in "combatting hepatitis" as per the SDG [30]. The restriction to this age group is because HBV infections among children below 5 years of age contribute most to the burden of chronic infections among adults [12]. The incidence of HCV infection is measured in the whole population (C.9.b). There is a mortality indicator designated for HBV (C.10.a) and HCV (C.10.b).

\section{Practical Implementation of the Monitoring and Evaluation Framework}

The data systems needed to report against the core indicators of the monitoring and evaluation framework for viral hepatitis (Table 2) include the following:

- C.1: regular biomarker surveys to estimate the prevalence of $\mathrm{HBV}$ and $\mathrm{HCV}$ infection (see the Surveillance for Chronic Infections section below). This could be coordinated with HIV surveys [31] and surveys to evaluate the impact of hepatitis B immunization [32].

- C.2: program data or health care facility surveys to estimate the ratio of facilities that can test for HBV and $\mathrm{HCV}$ infection per 100,000 population. This is compatible with the indicators for laboratory diagnosis capacity measured in the context of the SDGs and compatible with the WHO-recommended approach for survey of health care facilities (Service Availability and Readiness Assessment [SARA]) [33].

- C.3: routine data from the Expanded Program on Immunization to estimate vaccine coverage (estimates generated by WHO and UNICEF [United Nations International Children's Emergency Fund] are available on the Web) [34]. 
- C.4: program data on needle and syringe distribution that reflects broader harm reduction activities (using the same data sources as for HIV).

- C.5: population surveys or health care facility surveys to estimate the proportion of safe injections [28]. This can be coordinated with other population surveys or with SARA [33].

- C.6-7-8: data from a patient's database to monitor the cascade of diagnosis and treatment. In the absence of a separate database, unique identifiers allow patients to be tracked along the cascade and link patients across disease registries, clinics, and vital statistics. This can be coordinated with monitoring of patients with HIV infection where clinics routinely diagnose and treat hepatitis and HIV or in epidemics characterized by high prevalence of coinfection [7].

- C.9.a: biomarker survey in children who were vaccinated to estimate the impact of hepatitis B immunization on the cumulated incidence of chronic HBV infection [32]. This may be difficult to coordinate with household surveys that incorporate HIV testing (AIDS indicator surveys or public health impact assessments) because of sample size requirements and age group considerations [32].

- C.9.b: modeling estimates from biomarker surveys in the population (or specific groups) and trends on enhanced case reporting for acute hepatitis $\mathrm{C} 8$ to estimate the incidence of HCV infection (see the Surveillance for Acute Hepatitis section below). This could be coordinated with HIV modeling activities, where relevant, depending on the type of epidemic [31].

- C.10: combination of vital statistics data on the mortality from hepatocellular carcinoma and cirrhosis processed with data on the prevalence of $\mathrm{HBV}$ and $\mathrm{HCV}$ infection in patients with these sequelae (See the Surveillance for Sequelae section below).

\section{Surveillance for Viral Hepatitis}

Surveillance for viral hepatitis refers to the systematic, ongoing collection, transmission, analysis, and use of epidemiological data on viral hepatitis [8]. Surveillance focuses on epidemiological parameters such as incidence, prevalence, and mortality. The WHO monitoring and evaluation framework for viral hepatitis B and C addresses other components, such as behaviors. Surveillance for viral hepatitis has 3 components (see Table 3) that correspond to the natural history of HBV and HCV infections. These are as follows: (1) surveillance for acute hepatitis that reflects new infections, (2) surveillance for chronic, prevalent infections, and (3) surveillance for sequelae, including cirrhosis and hepatocellular carcinoma. These 3 components contribute to a comprehensive picture of the epidemiological situation of viral hepatitis. They feed the viral hepatitis monitoring and evaluation framework with key data (Multimedia Appendix 1). However, they may be implemented by different actors in a country's public health system. Thus, these different actors must coordinate to consolidate and triangulate pieces of information from different sources. As for all surveillance activities, standardized case definitions are essential to viral hepatitis surveillance, including surveillance for acute hepatitis and chronic infections (Table 4).

\section{Surveillance for Acute Hepatitis}

The majority of new infections with hepatitis viruses are asymptomatic or undiagnosed. However, surveillance for acute hepatitis can be informative through capturing a constant fraction of cases. Surveillance for acute hepatitis is usually implemented in the context of communicable disease surveillance systems. It differs from reporting of newly diagnosed cases of chronic infections that must be handled through patient registries (see the Patients Database section below). The WHO formulated standardized case definitions for surveillance for acute hepatitis (Table 4) [8]. In the field of surveillance for acute hepatitis, 2 different activities need to be distinguished: syndromic surveillance and enhanced case reporting.

Syndromic surveillance for undifferentiated acute viral hepatitis involves reporting by all health care facilities of clinical cases of acute hepatitis in the absence of in vitro diagnosis. This type of surveillance may detect large outbreaks, which are usually outbreaks of hepatitis A or E. However, surveillance for undifferentiated acute viral hepatitis is not essential to eliminate hepatitis $\mathrm{B}$ and $\mathrm{C}$ as public health threats.

Enhanced case reporting involves reporting by health care facilities of cases of acute hepatitis, by type (ie, A, B, C, D, or E), with in vitro diagnosis (ie, IgM tests) and collection of information of possible exposures. Cases of acute hepatitis are uniquely informative as they denote recent infections. Hence, collection of information on possible exposures during the referent exposure period (or the incubation period) informs on sources of infection. Enhanced case reporting may be difficult to implement countrywide. Hence, countrywide enhanced case reporting is mostly limited to high-income countries. However, in resource-limited settings, it can be done in sentinel sites where there is access to good in vitro diagnosis (eg, emergency departments). Enhanced case reporting allows description of trends in type-specific acute hepatitis and contributes to the generation of hypotheses regarding prevailing risk factors in a given setting. If enhanced case reporting is in place countrywide, it is probably implemented in the context of the communicable disease surveillance system. In the absence of a national system, a small number of sentinel sites may be needed, for example, in selected hospitals where $\operatorname{IgM}$ in vitro diagnosis is available for the diagnosis of recent infections. Monitoring the strength of the association between health care or injection drug use and new HBV or HCV infection can be beneficial to HIV prevention. HBV [35] and HCV [36] are more easily transmitted through percutaneous exposures than HIV [37]. New HBV and HCV infections are also easier to detect. Therefore, documentation of transmission of $\mathrm{HBV}$ or $\mathrm{HCV}$ through these routes using surveillance of acute hepatitis can provide early warning signals for the risk of HIV transmission, as recently illustrated with the outbreak of HBV and HCV associated with injection drug use in the United States $[38,39]$. 
Table 3. Surveillance activities needed to describe the epidemiology of viral hepatitis, including hepatitis B and hepatitis C.

\begin{tabular}{|c|c|c|c|c|c|}
\hline \multirow{3}{*}{$\begin{array}{l}\text { Parameter } \\
\text { Activities }\end{array}$} & \multirow{2}{*}{\multicolumn{2}{|c|}{$\begin{array}{l}\text { Activities that contribute to surveillance for viral hepatitis } \\
\text { Surveillance for acute hepatitis that reflect new infections }\end{array}$}} & \multirow{2}{*}{\multicolumn{2}{|c|}{ Surveillance for chronic, prevalent hepatitis }} & \multirow{3}{*}{$\begin{array}{l}\begin{array}{l}\text { Surveillance for } \\
\text { sequelae }\end{array} \\
\text { Combination of } \\
\text { data from cancer } \\
\text { registries, death } \\
\text { certificates, and } \\
\text { testing of cirrhosis } \\
\text { and } \mathrm{HCC}^{\mathrm{c}} \text { patients } \\
\text { for } \mathrm{HBV}^{\mathrm{d}} \text { and } \\
\mathrm{HCV}^{\mathrm{e}} \text { infection }\end{array}$} \\
\hline & & & & & \\
\hline & $\begin{array}{l}\text { Syndromic surveillance in } \\
\text { the general population; } \\
\text { Event-based surveillance }^{\mathrm{a}}\end{array}$ & $\begin{array}{l}\text { Enhanced case reporting } \\
\text { (with in vitro diagnosis and } \\
\text { collection of information on } \\
\text { risk factors) countrywide or } \\
\text { in sentinel sites }\end{array}$ & $\begin{array}{l}\text { Case reporting from } \\
\text { laboratories or health } \\
\text { care facilities }\end{array}$ & $\begin{array}{l}\text { Regular biomarker } \\
\text { surveys }\end{array}$ & \\
\hline $\begin{array}{l}\text { Population under } \\
\text { surveillance }\end{array}$ & $\begin{array}{l}\text { Persons presenting with } \\
\text { acute hepatitis in health care } \\
\text { facilities (discrete onset of } \\
\text { symptoms) }\end{array}$ & $\begin{array}{l}\text { Persons presenting with } \\
\text { acute hepatitis in health care } \\
\text { facilities (discrete onset of } \\
\text { symptoms) }\end{array}$ & $\begin{array}{l}\text { Persons without acute } \\
\text { symptoms tested in } \\
\text { health care facili- } \\
\text { ties/laboratories }\end{array}$ & $\begin{array}{l}\text { Person without acute } \\
\text { symptoms tested } \\
\text { during population } \\
\text { surveys }\end{array}$ & $\begin{array}{l}\text { Persons diagnosed } \\
\text { with cirrhosis and } \\
\text { HCC }\end{array}$ \\
\hline Usual implementer & $\begin{array}{l}\text { Communicable disease } \\
\text { surveillance }\end{array}$ & $\begin{array}{l}\text { Communicable disease } \\
\text { surveillance (if country- } \\
\text { wide); hepatitis program (if } \\
\text { sentinel sites) }\end{array}$ & $\begin{array}{l}\text { Communicable dis- } \\
\text { ease surveillance } \\
\text { and/or hepatitis pro- } \\
\text { gram }\end{array}$ & $\begin{array}{l}\text { Hepatitis program in } \\
\text { coordination with } \\
\text { the other actors im- } \\
\text { plementing } \\
\text { biomarker surveys }\end{array}$ & $\begin{array}{l}\text { Hepatitis program } \\
\text { collating data from } \\
\text { various different } \\
\text { sources, including } \\
\text { vital registration }\end{array}$ \\
\hline $\begin{array}{l}\text { Case definitions to } \\
\text { use (see Table } 4 \text { ) }\end{array}$ & $\begin{array}{l}\text { Presumptive case of acute } \\
\text { hepatitis }\end{array}$ & $\begin{array}{l}\text { Confirmed case of acute } \\
\text { hepatitis (by type) }\end{array}$ & $\begin{array}{l}\text { Chronic HBV and } \\
\text { HCV infection; sero- } \\
\text { logical evidence of } \\
\text { past or present HCV } \\
\text { infection }\end{array}$ & $\begin{array}{l}\text { Chronic HBV and } \\
\text { HCV infection; } \\
\text { serological evidence } \\
\text { of past or present } \\
\text { HCV infection }\end{array}$ & $\begin{array}{l}\text { Cases of HCC or } \\
\text { cirrhosis with } \\
\text { chronic HBV or } \\
\text { HCV infection }\end{array}$ \\
\hline $\begin{array}{l}\text { Objective of the } \\
\text { surveillance activity }\end{array}$ & Detect outbreaks & $\begin{array}{l}\text { Describe trends in type-spe- } \\
\text { cific acute hepatitis }{ }^{\mathrm{f}} \text { and } \\
\text { identify risk factors }\end{array}$ & $\begin{array}{l}\text { Estimate the propor- } \\
\text { tion of chronically in- } \\
\text { fected persons who } \\
\text { have been identified }\end{array}$ & $\begin{array}{l}\text { Estimate the burden } \\
\text { of chronic infec- } \\
\text { tions; model inci- } \\
\text { dence trends }\end{array}$ & $\begin{array}{l}\text { Estimate the inci- } \\
\text { dence of HCC and } \\
\text { cirrhosis }\end{array}$ \\
\hline
\end{tabular}

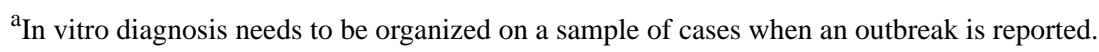

${ }^{b}$ High-quality data (ie, reliable in vitro diagnosis and good information on risk factors) from a smaller number of tertiary centers is preferable and more efficient than poor-quality data from many sites.

${ }^{\mathrm{c}} \mathrm{HCC}$ : hepatocellular carcinoma.

${ }^{\mathrm{d}} \mathrm{HBV}$ : hepatitis B virus.

${ }^{\mathrm{e}} \mathrm{HCV}$ : hepatitis $\mathrm{C}$ virus.

${ }^{\mathrm{f}}$ Surveillance for acute hepatitis cannot be used directly to quantify new infections. The reported number of cases of acute hepatitis needs to be adjusted for the large proportion of asymptomatic cases and underreporting. 
Table 4. World Health Organization (WHO) surveillance case definitions for viral hepatitis. Case definitions are for the purpose of reporting and surveillance and may differ from criteria to be used for the management of patients.

\begin{tabular}{|c|c|c|c|c|c|}
\hline \multirow[t]{2}{*}{ Stage of infection } & \multirow[t]{2}{*}{ Criteria } & \multicolumn{4}{|l|}{ Types of viral hepatitis } \\
\hline & & Hepatitis A & Hepatitis E & Hepatitis B & Hepatitis C \\
\hline \multirow[t]{2}{*}{ Acute hepatitis } & $\begin{array}{l}\text { Presumptive case: } \\
\text { clinical criteria }\end{array}$ & $\begin{array}{l}\text { Discrete onset of an acute } \\
\text { illness with signs/symp- } \\
\text { toms of acute infectious } \\
\text { illness (eg, fever, } \\
\text { malaise, and fatigue) and } \\
\text { liver damage (eg, } \\
\text { anorexia, nausea, jaun- } \\
\text { dice, dark urine, right } \\
\text { upper quadrant tender- } \\
\text { ness, OR raised ALT } \\
\text { levels more than } 10 \text { times } \\
\text { the upper limit of normal } \\
\text { of the laboratory) }^{\text {b }}\end{array}$ & $\begin{array}{l}\text { Discrete onset of an acute } \\
\text { illness with signs/symp- } \\
\text { toms of acute infectious } \\
\text { illness (eg, fever, } \\
\text { malaise, and fatigue) and } \\
\text { liver damage (eg, } \\
\text { anorexia, nausea, jaun- } \\
\text { dice, dark urine, right } \\
\text { upper quadrant tender- } \\
\text { ness, OR raised ALT } \\
\text { levels more than } 10 \text { times } \\
\text { the upper limit of normal } \\
\text { of the laboratory) }\end{array}$ & $\begin{array}{l}\text { Discrete onset of an acute } \\
\text { illness with signs/symp- } \\
\text { toms of acute infectious } \\
\text { illness (eg, fever, } \\
\text { malaise, and fatigue) and } \\
\text { liver damage (eg, } \\
\text { anorexia, nausea, jaun- } \\
\text { dice, dark urine, right } \\
\text { upper quadrant tender- } \\
\text { ness, OR raised ALT } \\
\text { levels more than } 10 \text { times } \\
\text { the upper limit of normal } \\
\text { of the laboratory) }\end{array}$ & $\begin{array}{l}\text { Discrete onset of an } \\
\text { acute illness with } \\
\text { signs/symptoms of } \\
\text { acute infectious illness } \\
\text { (eg, fever, malaise, and } \\
\text { fatigue) and liver dam- } \\
\text { age (eg, anorexia, nau- } \\
\text { sea, jaundice, dark } \\
\text { urine, right upper quad- } \\
\text { rant tenderness, OR } \\
\text { raised ALT levels more } \\
\text { than } 10 \text { times the upper } \\
\text { limit of normal of the } \\
\text { laboratory) }\end{array}$ \\
\hline & $\begin{array}{l}\text { Confirmed case: } \\
\text { clinical criteria } \\
\text { AND biomarker or } \\
\text { epidemiological } \\
\text { criteria }\end{array}$ & $\begin{array}{l}\text { IgM }^{\mathrm{c}} \text { anti-HAV } \\
\text { Epidemiological link } \\
\text { with a confirmed case }\end{array}$ & $\begin{array}{l}\text { IgM anti-HEV }+ \text { ve OR } \\
\text { Epidemiological link } \\
\text { with a confirmed case }\end{array}$ & $\operatorname{IgM}$ anti-HBc ${ }^{\mathrm{f}}+\mathrm{ve}^{\mathrm{g}}$ & $\begin{array}{l}\mathrm{HCV}^{\mathrm{h}} \mathrm{RNA}^{\mathrm{i}}+\mathrm{ve} \text { and } \\
\text { anti-HCV }{ }^{\mathrm{j}} \text {-ve OR Sero-- } \\
\text { conversion to anti- } \\
\mathrm{HCV}^{\mathrm{k}} \text { OR Anti-HCV } \\
\text { +ve AND IgM anti- } \\
\mathrm{HBc} \text {-ve AND Anti- } \\
\mathrm{HAV} \text { IgM -ve AND } \\
\text { Anti-HEV IgM -ve }\end{array}$ \\
\hline \multirow{2}{*}{$\begin{array}{l}\text { Chronic infections } \\
\text { (Only confirmed } \\
\text { cases that all require } \\
\text { clinical and } \\
\text { biomarker criteria) }\end{array}$} & Clinical criteria & Not applicable & $\begin{array}{l}\text { Rare event, no WHO } \\
\text { standard case definition }\end{array}$ & $\begin{array}{l}\text { Person } \text { not meeting the } \\
\text { case definition for acute } \\
\text { hepatitis } 1\end{array}$ & $\begin{array}{l}\text { Person not meeting the } \\
\text { case definition for acute } \\
\text { hepatitis }{ }^{1}\end{array}$ \\
\hline & Biomarker criteria & Not applicable & $\begin{array}{l}\text { Rare event, no WHO } \\
\text { standard case definition }\end{array}$ & $\mathrm{HBsAg}+\mathrm{ve} \mathrm{e}^{\mathrm{m}, \mathrm{n}}$ & $\begin{array}{l}\text { HCV RNA +ve OR } \\
\text { HCV Ag +ve }\end{array}$ \\
\hline
\end{tabular}

\footnotetext{
${ }^{\mathrm{a} A L T}$ : alanine aminotransferase.

${ }^{\mathrm{b}}$ Ten times the upper limit of normal (400 IU/L) is the threshold used by the United States' State and Territorial Epidemiologists (CSTE). Countries may also select lower (more sensitive) or higher (more specific) thresholds.

${ }^{\mathrm{c}} \mathrm{Ig}$ : immunoglobulin.

danti-HAV: antibody against hepatitis A virus.

eanti-HEV: antibody against hepatitis E virus.

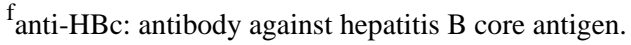

${ }^{g}$ Hepatitis test panels usually include $\mathrm{HBsAg}$ with anti-HBc IgM test (positive predictive value of anti-HBc IgM is higher if $\mathrm{HBsAg}$ is $+\mathrm{ve}$ ). Specific test/threshold needed to exclude transient IgM during flares in chronic hepatitis B virus (HBV) infection.

${ }^{\mathrm{h}} \mathrm{HCV}$ : hepatitis $\mathrm{C}$ virus.

${ }^{\mathrm{i}} \mathrm{RNA}$ : ribonucleic acid.

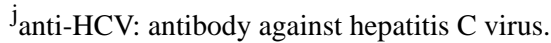

${ }^{\mathrm{k}}$ Among patients tested regularly at short time intervals, seroconversion to anti-HCV suggests a recent HCV infection. Seroconversions to anti-HCV should be followed by reflex RNA test (when available).

${ }^{1}$ Person tested in the context of the evaluation of a chronic liver disease, a check-up, or a survey.


than HBsAg alone.

${ }^{\mathrm{n}} \mathrm{HBsAg}$ : hepatitis B surface antigen.
}

\section{Surveillance for Chronic Infections}

The reference method for surveillance for chronic infections is regular biomarker surveys. When the opportunity to conduct population-based surveys is not available, data mining can also be undertaken to collate existing data on HBV or HCV infection [8]. Reporting cases of chronic infections present in health care facilities is not informative in terms of surveillance for chronic infections. This should be seen more as a way to monitor treatment in the context of a national database of patients with $\mathrm{HBV}$ or HCV infection (see the Patients Database section below) [8].

Regular biomarker surveys are the method of reference to estimate the prevalence of chronic infections in the general population. The viral hepatitis program can organize such 
biomarker surveys alone or in coordination with Demographic and Health Surveys, AIDS indicator surveys, or population HIV impact assessments that provide opportunities for coordination (depending on target populations, age groups, and sample sizes) [31]. Planning this integration ahead of time to include HIV, $\mathrm{HBV}$, and HCV as part of the objectives of the survey may be better than testing stored specimens. Testing stored sera may raise methodological issues when specimens are not available from all study participants [40]. It can also raise ethical issues if participants identified with $\mathrm{HBV}$ or $\mathrm{HCV}$ cannot be linked to care [8]. The WHO prepared a template protocol to conduct biomarker surveys for viral hepatitis. This protocol will be available from the WHO upon request while in draft form and will be made available electronically on the Web when finalized. In addition to surveys conducted in the general population, surveys among specific groups (eg, PWID and men who have sex with men) can inform about risk behaviors and the prevalence of infection in these groups. This type of surveillance is often conducted in the context of HIV programs. Information from such surveys in specific populations may be used in combination with information from the general population to estimate the overall size of the infected population.

Reporting of cases of chronic $H B V$ and $H C V$ infections from health care facilities can be implemented in the context of a database of chronically infected patients (see the Patients Database section below) that documents the cascade of diagnosis, care, and treatment. Cases of chronic infection reported from health care facilities estimate the number of cases diagnosed. Reporting systems for these cases of chronic infections need to be completely separate from systems to report acute hepatitis. Reporting of cases of acute hepatitis is done for a different objective, which is to estimate incidence and identify risk factors for new infections. The practice of reporting cases of chronic infection together with cases of acute hepatitis may lead to a database that contains cases of acute hepatitis diluted in a larger number of chronic infections. This complicates interpretation of the data on acute hepatitis. Acute hepatitis data are particularly useful because they reflect recent infections. If they are merged with data on chronic infections for which the date of infection is unknown, they lose specificity and usefulness.

\section{Surveillance for Sequelae (Including Mortality)}

Viral hepatitis-associated mortality is spread across various causes of death in vital registration systems. These include acute hepatitis (that accounts for a small proportion of deaths), cirrhosis, and hepatocellular carcinoma (for which the link with HBV and HCV infection is not documented in the death certificates) [41]. To quantify deaths from the sequelae of HBV and $\mathrm{HCV}$ infections, the WHO proposes to start from the mortality envelope from sequelae (the deaths from cirrhosis and hepatocellular carcinoma from vital registration data) and to correct it on the basis of the fraction of these sequelae that are attributable to HBV and HCV infection. This may be done using national data on the prevalence of $\mathrm{HBV}$ and $\mathrm{HCV}$ infection among patients with cirrhosis and hepatocellular carcinoma. Such estimates may be obtained from published studies, unpublished data, or regional estimates $[18,42]$.

\section{Patient Database for Testing and Treatment}

At an early stage of a program, estimates describing the cascade of testing and treatment may be obtained from ad hoc mechanisms (eg, surveys and data on sales of medicines). However, the best approach to monitor and evaluate a national program for testing and treatment of $\mathrm{HBV}$ and $\mathrm{HCV}$ infection is to establish a national database of persons with chronic infections.

If feasible, combining case reporting and patient monitoring systems can create a national database of patients with chronic $\mathrm{HBV}$ and HCV infection. Health care providers can use such databases to manage data on personal characteristics, diagnosis, treatment initiation or deferral, monitoring, and viral suppression/cure. When a person is diagnosed (ie, newly identified cases of chronic infection), his/her record is added to the database. The record is censored when the person is cured or dies. The system may be made of standardized patient cards, paper registers, or an electronic data entry system. If data collection is paper-based, information then needs to be entered on a computer. Unique identifiers are necessary to identify and remove duplicate reports (ie, deduplication) and to protect confidentiality of patients. They can also be used to follow individuals along the cascade of services over the medium term and as they move between facilities. Automated data analysis can then aggregate individual data and calculate core indicators on treatment coverage/initiation (C.7.a/C.7.b) and viral suppression/cure (C.8.a/C.8.b) using a cohort approach. From 2017, the WHO will be assisting countries through the preparation of a template patient card, database metadata, and analyses plans that will allow setting up electronic patient registries. However, ideally, such a database should be compatible with other existing health information systems, such as the one used for HIV.

\section{Coinfections}

About 2.3 million people living with HIV are coinfected with HCV [43] and 2.6 million with HBV [44,45]. HBV-HIV coinfection became easier to handle as the first-line recommended antiretroviral regimens now include tenofovir, which would also effectively treat HBV infection [46]. With respect to HCV-HIV coinfection, testing of HIV-infected patients for $\mathrm{HCV}$ infection is necessary as coinfection requires specific management and treatment [13]. HCV treatment may be administered before HIV treatment if the patient is not immunosuppressed. If the patient is immunosuppressed, HIV treatment needs to be started first, and the HCV treatment regimen will need to be adapted to avoid drug interactions [13].

The consolidated strategic information guidelines for HIV included two indicators for coinfection, LINK 27 for HBV and LINK 28 for HCV [7]. LINK 27 and LINK 28 reflect the proportion of patients in care for HIV that have been screened for $\mathrm{HBV}$ and $\mathrm{HCV}$, respectively. In 2016, in view of the new "treat all" HIV treatment guidelines, the WHO proposed to amend the LINK 27/28 indicators so that the numerator would be the number of persons newly placed on anti-retroviral treatment screened for hepatitis $\mathrm{B} / \mathrm{C}$ during the reporting period and the denominator would be the number of persons newly placed on ART. For HCV infection, testing for HCV infection 
would mean implementing the full testing strategy that includes $\mathrm{HCV}$ nucleic acid test testing if the patient is anti-HCV positive. This modification would best reflect the need to look for hepatitis before starting treatment. It will help ensure that HBV-infected patients are placed on tenofovir-based therapy and that $\mathrm{HCV}$-infected people are being considered for specific treatment.

\section{Conclusions}

The many commonalities between HIV, HBV, and HCV in terms of the diseases that they cause and response required justify implementation of the programs with coordination, strategic linkages, or integration, according to the respective magnitudes of the HIV and viral hepatitis epidemics. These articulations should be considered at the strategic, policy, technical, and implementation levels. Alignment of the collection, analysis, and use of strategic information are critical areas of this coordinated implementation. The WHO monitoring and evaluation frameworks for HIV, HBV, and HCV have been constructed using a similar logic to facilitate alignment. However, the differences between HIV, HBV, and HCV call for collaborations with other areas of work to ensure a comprehensive approach. These include communicable disease surveillance for acute hepatitis surveillance, immunization, and hepatology centers for sequelae surveillance. The focus of the SDGs on a single health goal and the similarities in the targets for $\mathrm{HIV}, \mathrm{HBV}, \mathrm{HCV}$, and tuberculosis mean that the overarching priority would be to integrate viral hepatitis strategic information and HIV strategic information within the broader existing health information systems and thus contribute toward strengthening the health system. With this approach, a coordinated incremental investment in the data system will provide the evidence base needed to guide elimination of viral hepatitis.

\section{Acknowledgments}

The authors are grateful to Andrew Ball, Peter Ghys, and Peter Godfrey-Faussett for useful comments and suggestions on the manuscript.

\section{Conflicts of Interest}

None declared.

\section{Multimedia Appendix 1}

Monitoring and evaluation framework.

[PDF File (Adobe PDF File), 32KB-Multimedia Appendix 1]

\section{References}

1. World Health Organization. 2017 Apr. Global hepatitis report, 2017 URL: http://www.who.int/hepatitis/publications/ global-hepatitis-report2017/en/[WebCite Cache ID 6uVoLg3IA]

2. GBD 2013 Mortality and Causes of Death Collaborators. Global, regional, and national age-sex specific all-cause and cause-specific mortality for 240 causes of death, 1990-2013: a systematic analysis for the Global Burden of Disease Study 2013. Lancet 2015 Jan 10;385(9963):117-171 [FREE Full text] [doi: 10.1016/S0140-6736(14)61682-2] [Medline: 25530442]

3. World Health Organization. 2016 Jun. Global health sector strategy on viral hepatitis, 2016-2021 URL: http://apps.who.int/ iris/bitstream/10665/246177/1/WHO-HIV-2016.06-eng.pdf?ua=1[WebCite Cache ID 6um8mCBhx]

4. World Health Organization. 2016. Global health sector strategy on HIV, 2016-2021 URL: http://apps.who.int/iris/bitstream/ 10665/246178/1/WHO-HIV-2016.05-eng.pdf?ua=1[WebCite Cache ID 6um8soxXT]

5. World Health Organization. Global health sector strategy on sexually transmitted infections, 2016-2021 URL: http://www. who.int/reproductivehealth/publications/rtis/ghss-stis/en/[WebCite Cache ID 6um92tq1T]

6. No authors listed. Hepatitis B vaccines. Wkly Epidemiol Rec 2009;84(40):405-419. [Medline: 19817017]

7. World Health Organization. 2015. Consolidated strategic information guidelines for HIV in the health sector URL: http:/ lapps.who.int/iris/bitstream/10665/164716/1/9789241508759 eng.pdf?ua=1\&ua=1

8. World Health Organization. 2016. Technical considerations and case definitions to improve surveillance for viral hepatitis URL: http://apps.who.int/iris/bitstream/10665/204501/1/9789241549547 eng.pdf?ua=1[WebCite Cache ID 6um9EqnxX]

9. World Health Organization. 2016. Monitoring and evaluation for viral hepatitis B and C: recommended indicators and framework URL: http://apps.who.int/iris/bitstream/10665/204790/1/9789241510288 eng.pdf[WebCite Cache ID 6um9GZLmV]

10. Fenton KA, Aquino GA, Dean HD. Program collaboration and service integration in the prevention and control of HIV infection, viral hepatitis, STDs, and tuberculosis in the U.S.: lessons learned from the field. Public Health Rep 2014;129 Suppl 1:1-4 [FREE Full text] [doi: 10.1177/00333549141291S101] [Medline: 24385642]

11. Okulicz F, Lambotte O. Epidemiology and clinical characteristics of elite controllers. Curr Opin HIV AIDS 2011 May;6(3):163-168. [doi: 10.1097/COH.0b013e328344f35e] [Medline: 21502920]

12. Edmunds WJ, Medley GF, Nokes DJ, Hall AJ, Whittle HC. The influence of age on the development of the hepatitis B carrier state. Proc Biol Sci 1993 Aug 23;253(1337):197-201. [doi: 10.1098/rspb.1993.0102] [Medline: $\underline{\text { 8397416] }}$ 
13. World Health Organization. Guidelines for the screening, care and treatment of persons with chronic hepatitis $\mathrm{C}$ infection. 2016. URL: http://apps.who.int/iris/bitstream/10665/205035/1/9789241549615 eng.pdf?ua=1[WebCite Cache ID 6um9cXxFz]

14. Stover J, Johnson P, Zaba B, Zwahlen M, Dabis F, Ekpini RE. The Spectrum projection package: improvements in estimating mortality, ART needs, PMTCT impact and uncertainty bounds. Sex Transm Infect 2008 Aug;84 Suppl 1:i24-i30 [FREE Full text] [doi: 10.1136/sti.2008.029868] [Medline: 18647862]

15. Chen JD, Yang HI, Iloeje UH, You SL, Lu SN, Wang LY, Risk Evaluation of Viral Load Elevation and Associated Liver Disease/Cancer in HBV (REVEAL-HBV) Study Group. Carriers of inactive hepatitis B virus are still at risk for hepatocellular carcinoma and liver-related death. Gastroenterology 2010 May;138(5):1747-1754. [doi: 10.1053/j.gastro.2010.01.042] [Medline: 20114048]

16. Chu C, Liaw Y. Incidence and risk factors of progression to cirrhosis in inactive carriers of hepatitis B virus. Am J Gastroenterol 2009 Jul;104(7):1693-1699. [doi: 10.1038/ajg.2009.187] [Medline: 19455130]

17. Thein HH, Yi Q, Dore GJ, Krahn MD. Estimation of stage-specific fibrosis progression rates in chronic hepatitis C virus infection: a meta-analysis and meta-regression. Hepatology 2008 Aug;48(2):418-431. [doi: 10.1002/hep.22375] [Medline: $\underline{18563841]}$

18. Perz JF, Armstrong GL, Farrington LA, Hutin YJ, Bell BP. The contributions of hepatitis B virus and hepatitis C virus infections to cirrhosis and primary liver cancer worldwide. J Hepatol 2006 Oct;45(4):529-538. [doi:

10.1016/j.jhep.2006.05.013] [Medline: 16879891]

19. Ramos-Casals M, Zignego AL, Ferri C, Brito-Zerón P, Retamozo S, Casato M, International Study Group of Extrahepatic Manifestations related to HCV (ISG-EHCV). Evidence-based recommendations on the management of extrahepatic manifestations of chronic hepatitis C virus infection. J Hepatol 2017 Jun;66(6):1282-1299. [doi: 10.1016/j.jhep.2017.02.010] [Medline: 28219772]

20. Pépin J, Abou Chakra CN, Pépin E, Nault V, Valiquette L. Evolution of the global burden of viral infections from unsafe medical injections, 2000-2010. PLoS One 2014 Jun 9;9(6):e99677 [FREE Full text] [doi: 10.1371/journal.pone.0099677] [Medline: 24911341]

21. Vun MC, Galang RR, Fujita M, Killam W, Gokhale R, Pitman J, Roka Cluster Investigation Team. Cluster of HIV infections attributed to unsafe injection practices--Cambodia, December 1, 2014-February 28, 2015. MMWR Morb Mortal Wkly Rep 2016 Feb 19;65(6):142-145 [FREE Full text] [doi: 10.15585/mmwr.mm6506a2] [Medline: 26890340]

22. Yeung CY, Lee HC, Chan WT, Jiang CB, Chang SW, Chuang CK. Vertical transmission of hepatitis C virus: current knowledge and perspectives. World J Hepatol 2014 Sep 27;6(9):643-651 [FREE Full text] [doi: 10.4254/wjh.v6.i9.643] [Medline: 25276280]

23. World Health Organization. 2015. Guidelines for the prevention, care and treatment of persons with chronic hepatitis B infection URL: http://apps.who.int/iris/bitstream/10665/154590/1/9789241549059 eng.pdf?ua=1\&ua=1

24. Sustainabledevelopment.un. New York: United Nations; 2015. Sustainable Development Knowledge Platform: Sustainable Development Goals URL: https://sustainabledevelopment.un.org/sdgs [accessed 2017-11-06] [WebCite Cache ID 6umAENOEK]

25. World Health Organization. 2016. Combating hepatitis B and C to reach elimination by 2030 URL: http://apps.who.int/ iris/bitstream/10665/206453/1/WHO HIV 2016.04 eng.pdf?ua=1[WebCite Cache ID 6umAH2R86]

26. Nayagam S, Thursz M, Sicuri E, Conteh L, Wiktor S, Low-Beer D, et al. Requirements for global elimination of hepatitis B: a modelling study. Lancet Infect Dis 2016 Dec;16(12):1399-1408 [FREE Full text] [doi: 10.1016/S1473-3099(16)30204-3] [Medline: 27638356]

27. World Health Organization, United Nations Office on Drugs and Crime, Joint United Nations Programme on HIV/AIDS. 2012. WHO, UNODC, UNAIDS technical guide for countries to set targets for universal access to HIV prevention, treatment and care for injecting drug users, 2012 revision URL: http://apps.who.int/iris/bitstream/10665/77969/1/9789241504379 eng. pdf[WebCite Cache ID 6umAN0e9k]

28. World Health Organization. 2008. Revised injection safety assessment tool URL: http://apps.who.int/medicinedocs/ documents/s15944e/s15944e.pdf [WebCite Cache ID 6umAQRcGB]

29. Mast EE, Alter MJ, Margolis HS. Strategies to prevent and control hepatitis B and C virus infections: a global perspective. Vaccine 1999 Mar 26;17(13-14):1730-1733. [Medline: 10194830]

30. World Health Organization. 2016. World health statistics 2016: monitoring health for the SDGs URL: http://apps.who.int/ iris/bitstream/10665/206498/1/9789241565264 eng.pdf?ua=1[WebCite Cache ID 6umCE34VB]

31. UNAIDS/WHO Working Group on Global HIV/AIDS and STI Surveillance 2015. Unaids. Geneva: UNAIDS; 2015. Monitoring HIV impact using population-based surveys URL: http://www.unaids.org/sites/default/files/media asset/ JC2763 PopulationBasedSurveys en.pdf [accessed 2017-11-06] [WebCite Cache ID 6umC8gyMH]

32. World Health Organization. Documenting the impact of hepatitis B immunization: best practices for conducting a serosurvey URL: http://apps.who.int/iris/bitstream/10665/70808/1/WHO IVB 11.08 eng.pdf[WebCite Cache ID 6umCByYgQ]

33. World Health Organization. 2015. Service Availability and Readiness Assessment (SARA): an annual monitoring system for service delivery. Reference manual, version 2.2. Revised July 2015 URL: http://apps.who.int/iris/bitstream/10665/ 149025/1/WHO HIS HSI 2014.5 eng.pdf?ua=1[WebCite Cache ID 6umC4iN5X] 
34. World Health Organization and Joint United Nations Programme on HIV/AIDS. 2017. WHO-UNICEF estimates of DTP3 coverage URL: http://apps.who.int/immunization monitoring/globalsummary/timeseries/tswucoveragedtp3.html[WebCite Cache ID 6umC0zkEo]

35. Werner BG, Grady GF. Accidental hepatitis-B-surface-antigen-positive inoculations. Use of e antigen to estimate infectivity. Ann Intern Med 1982 Sep;97(3):367-369. [Medline: 7114632]

36. Jagger J, Puro V, De Carli G. Occupational transmission of hepatitis C virus. J Am Med Assoc 2002 Sep 25;288(12):1469; author reply 1469-1469; author reply 1471. [Medline: 12243628]

37. Baggaley RF, Boily MC, White RG, Alary M. Risk of HIV-1 transmission for parenteral exposure and blood transfusion: a systematic review and meta-analysis. AIDS 2006 Apr 4;20(6):805-812. [doi: 10.1097/01.aids.0000218543.46963.6d] [Medline: 16549963]

38. Van Handel MM, Rose CE, Hallisey EJ, Kolling JL, Zibbell JE, Lewis B, et al. County-level vulnerability assessment for rapid dissemination of HIV or HCV infections among persons who inject drugs, United States. J Acquir Immune Defic Syndr 2016 Nov 1;73(3):323-331 [FREE Full text] [doi: 10.1097/QAI.0000000000001098] [Medline: 27763996]

39. Harris AM, Iqbal K, Schillie S, Britton J, Kainer MA, Tressler S, et al. Increases in acute hepatitis B virus infections Kentucky, Tennessee, and West Virginia, 2006-2013. MMWR Morb Mortal Wkly Rep 2016 Jan 29;65(3):47-50 [FREE Full text] [doi: 10.15585/mmwr.mm6503a2] [Medline: 26821369]

40. Ly KN, Kim AA, Umuro M, Drobenuic J, Williamson JM, Montgomery JM, et al. Prevalence of hepatitis B virus infection in Kenya, 2007. Am J Trop Med Hyg 2016 Aug 3;95(2):348-353 [FREE Full text] [doi: 10.4269/ajtmh.16-0059] [Medline: 27273644]

41. Mahajan R, Xing J, Liu SJ, Ly KN, Moorman AC, Rupp L, Chronic Hepatitis Cohort Study (CHeCS) Investigators. Mortality among persons in care with hepatitis C virus infection: the Chronic Hepatitis Cohort Study (CHeCS), 2006-2010. Clin Infect Dis 2014 Apr;58(8):1055-1061. [doi: 10.1093/cid/ciu077] [Medline: 24523214]

42. de Martel C, Maucort-Boulch D, Plummer M, Franceschi S. World-wide relative contribution of hepatitis B and C viruses in hepatocellular carcinoma. Hepatology 2015 Oct;62(4):1190-1200 [FREE Full text] [doi: 10.1002/hep.27969] [Medline: 26146815]

43. Platt L, Easterbrook P, Gower E, McDonald B, Sabin K, McGowan C, et al. Prevalence and burden of HCV co-infection in people living with HIV: a global systematic review and meta-analysis. Lancet Infect Dis 2016 Jul;16(7):797-808. [doi: 10.1016/S1473-3099(15)00485-5] [Medline: 26922272]

44. Easterbrook P, Platt L, Gower E, Razavi H, Sabin K, Vickerman P. Global systematic review and meta-analysis of the seroprevalence of HBV and HCV infection in HIV-infected persons. TUPEB 254 abstract. 2015 Jul 19 Presented at: 8th IAS Conference on Pathogenesis, Treatment and Prevention; July 19-22, 2015; Vancouver, BC, Canada.

45. Kourtis AP, Bulterys M, Hu DJ, Jamieson DJ. HIV-HBV coinfection — a global challenge. N Engl J Med 2012 May 10;366(19):1749-1752. [doi: 10.1056/NEJMp1201796] [Medline: 22571198]

46. World Health Organization. Geneva, Switzerland: World Health Organization; 2016. Consolidated guidelines on the use of antiretroviral drugs for treating and preventing HIV infection. Recommendations for a public health approach - Second edition URL: http://apps.who.int/iris/bitstream/10665/208825/1/9789241549684 eng.pdf?ua=1[WebCite Cache ID 6umCKEeCn]

\author{
Abbreviations \\ AIDS: acquired immune deficiency syndrome \\ ALT: alanine aminotransferase \\ anti-HAV: antibody against hepatitis A virus \\ anti-HBc: antibody against hepatitis $\mathrm{B}$ core antigen \\ anti-HCV: antibody against hepatitis $\mathrm{C}$ virus \\ anti-HEV: antibody against hepatitis $\mathrm{E}$ virus \\ GHSS: Global Health Sector Strategy \\ HBIg: Hepatitis B immune globulin \\ HBsAg: Hepatitis B surface antigen \\ HBV: hepatitis B virus \\ HCC: hepatocellular carcinoma \\ HCV: hepatitis $\mathrm{C}$ virus \\ Ig: immunoglobulin \\ PWID: people who inject drugs \\ RNA: ribonucleic acid \\ SARA: Service Availability and Readiness Assessment \\ SDGs: Sustainable Development Goals \\ STIs: sexually transmitted infections \\ UNICEF: United Nations International Children's Emergency Fund
}


WHO: World Health Organization

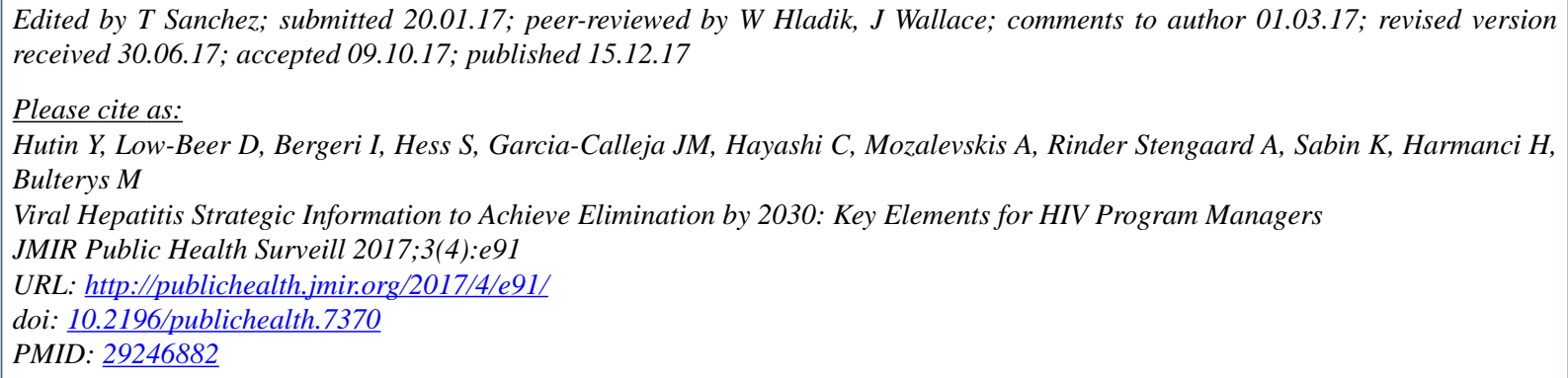

(C) Yvan Hutin, Daniel Low-Beer, Isabel Bergeri, Sarah Hess, Jesus Maria Garcia-Calleja, Chika Hayashi, Antons Mozalevskis, Annemarie Rinder Stengaard, Keith Sabin, Hande Harmanci, Marc Bulterys. Originally published in JMIR Public Health and Surveillance (http://publichealth.jmir.org), 15.12.2017. This is an open-access article distributed under the terms of the Creative Commons Attribution License (https://creativecommons.org/licenses/by/4.0/), which permits unrestricted use, distribution, and reproduction in any medium, provided the original work, first published in JMIR Public Health and Surveillance, is properly cited. The complete bibliographic information, a link to the original publication on http://publichealth.jmir.org, as well as this copyright and license information must be included. 